\title{
Implementasi Pertimbangan Hakim dalam Mengabulkan Permohonan Penetapan Wali Adhal Untuk Melaksanakan Perkawinan Menurut Hukum Islam (Studi Putusan Nomor 0055/ Pdt. P/ 2019/PA.Mt)
}

\author{
Baharudin \\ Fakultas Hukum, Universitas Bandar Lampung \\ Jln Zaenal Abidin Pagar Alam, Nomor 26 Labuhan Ratu Bandar Lampung, \\ Correspondence email: baharudin@ubl.ac.id
}

\begin{abstract}
Abstrak. Perkawinan harus memenuhi syarat dan rukunnya, salah satu rukun yang harus dipenuhi adalah adanya wali nikah.Keberadaan seorang wali dalam akad nikah adalah suatu yang mesti dan tidak sah akad perkawinan yang tidak dilakukan oleh wali.Wali itu ditempatkan sebagai rukun dalam perkawinan menurut kesepakatan ulama secara prinsip. Permasalahan dalam penelitian adalah bagaimana hokum formil dalan penetapan Pengadilan Agama Metro Nomor 0055/Pdt P/2019/PA.Mt tentang dikabulkannya Permohonan waliadhal? Dan apa dasar pertimbangan hakim (hukum materil) dalam memutuskan Penetapan Pengadilan Agama Metro Nomor 0055/Pdt P/2019/PA.Mt tentang dikabulkannya permohonan wali adhal? Metode penelitian menggunakan pendekatan yuridis normatif dan empiris. Jenis data yang digunakan adalah data sekunder dan data primer. Pengumpulan data melalui penelitian kepustakaan (library research) dan penelitian lapangan (field research). Analisis data yang digunakan adalah yuridiskualitatif. Hasil penelitian menunjukkan Hukum Formil dalam penetapan PengadilanAgama Metro No.0055/Pdt.P/2019/PA.Mt tentang dikabulkannya permohonan wali adhal, yaitu: Pengadilan Agama Metro telah mengabulkan permohonan wali adha ldan menetapkan wali hakim sebagai wali nikah dari anak perempuan (Pemohon) yang walinya adhal, maka Pengadilan Agama Metro mendasarkan pada Peraturan Menteri Agama No.2 Tahun1987 tentang wali hakim dan Kompilasi Hukum Islam Pasal 23 ayat (2). Dasar pertimbangan hakim (hukum materil) dalam memutuskan Penetapan Pengadilan Agama Metro Nomor 0055/Pdt.P/2019/PA.Mt tentang dikabulkannya permohonan wali adhal hakim melihat alasan penolakan wali tersebut tidak termasuk dalam alasan yang dibenarkan oleh hukum syara', karena alasan seorang wali yang tidak setuju dengan calon suami anaknya. Saran, kepada para Hakim dalam menetapkan suatu perkara tidak cukup hanya tertuju pada studi teks untuk menghasilkan sebuah keputusan yang adil.Wali nikah diharapkan lebih memikirkan serta mempertimbangkan kembali untuk menolak menjadi wali nikah bagi perkawinan anaknya sendiri karena anaknya sudah dewasa dan mempunyai niat baik untuk menikah. Pemohon dan calon suami diharapkan dapat menerima dengan baik alasan ataupun nasihat orang tua karena setiap orang tua pasti menginginkan yang terbaik untuk masa depan anak-anaknya selagi pilihan anaknya itu baik dan tidak menyimpang.
\end{abstract}

Kata Kunci: Implementasi; Pertimbangan Hakim; Wali Adhal; Perkawinan; Hukum Islam

\begin{abstract}
Marriage must meet the requirements and harmony, one pillar that must be met is the marriage guardian. The existence of a guardian in a marriage contract is a must and is not a legal marriage agreement that is not carried out by the guardian. The guardian is placed as a pillar in marriage according to the agreement of scholars in principle. The problem in this research is how is the formal law in the stipulation of Metro Religious Court Number 0055 / Pdt P / 2019 / PA.Mt regarding the application of guardian application? and what is the basis for the judge's judgment (material law) in deciding on the Establishment of the Metro Religious Court Number 0055 / Pdt P / 2019 / PA.Mt regarding the application of a guardian?. The research method uses a normative and empirical juridical approach. The type of data used is secondary data and primary data. Collecting data through library research and field research. Analysis of the data used is qualitative juridical.
\end{abstract}

Keywords: Implementation; Judge Considerations; Guardian Adhal; Marriage; Islamic Law

\section{PENDAHULUAN}

Negara Indonesia merupakan Negara yang berdasarkan atas hukum, sebagaimana yang diatur dalam Pasal 1 ayat (3) Jo. Pasal 27 ayat (1) Undang-Undang Dasar Republik Indonesia Tahun 1945 yaitu segala warga negara bersamaan kedudukannya di dalam hukum dan pemerintahan dan wajib menjunjung hukum dan pemerintahan itu dengan tidak ada kecualinya Jo. Pasal 28 D ayat (1) Undang-Undang Dasar Republik Indonesia Tahun 1945 yaitu setiap orang berhak atas pengakuan, jaminan, perlindungan dan kepastian hukum yang adil serta perlakuan yang sama dihadapan hukum.Maka setiap tindakan yang bertentangan atas Pancasiladan Undang-Undang Dasar 1945 (selanjutnya disebut UUD 1945) sebagai dasar hukum yang paling hakiki disamping produk-produk hokum lainnya.

Negara hukum adalah konsep yang berparadigma bahwa Negara dan alat kekuasaannya (pemerintah) tak dibenarkan bertindak atas kekuasaannya belaka, melainkan harus ditumpukan pada dasar kebenaran hukum yang telah 
dipositifkan ialah undang-undang yang pada gilirannya berdiri tegak di atas kebenaran hukum undang-undang yang paling dasar yaitu Undang-Undang Dasar $1945 .{ }^{1}$

Perkawinan merupakan kebutuhan hidup seluruh umat manusia sejak zama dahulu hingga saat ini, karena perkawinan merupakan masalah yan aktual untuk dibicarakan di dalam maupun diluar perturan hukum. Perkawinan akan timbul ikatan hukum antara suami dan istri dengan lahirnya anak akan timbul pula hubungan hukum antara orang tua dan anak-anak mereka, demikian juga kepemilikan harta kekayaan dengan perkawinan.

Menurut Undang-Undang Nomor 1 Tahun 1974, perkawinan adalah ikatan lahir batin antara seorang pria dengan seorang wanita sebagai suami istri dengan tujuan membentuk keluarga (rumahtangga) yang bahagia dan kekal berdasarkan Ketuhanan Yang Maha Esa. ${ }^{2}$

Undang-Undang Nomor 1 Tahun 1974 tentang perkawinan, bertujuan mengatur pergaulan hidup yang sempurna, bahagia dan kekal di dalam suatu rumah tangga guna terciptanya rasa kasih sayang dan saling mencintai. Namun demikian, pada kenyataanya sejarah umat manusia yang telah ribuan tahun membuktikan bahwa tidak semua itu dapat dicapai dengan mudah, bahkan sebaliknya kandas ataupun gagal sama sekali ditengah jalan, karena tidak tercapainya kata sepakat dari salah satu pihak ataupun perilaku kedua belah pihak yang bertentangan dengan ajaran agama, salah satunya mengenai perkawinan. ${ }^{3}$

Perkawinan harus memenuhi syarat dan rukunnya, salah satu rukun yang harus dipenuhi adalah adanya wali nikah. Keberadaan seorang wali dalam akad nikah adalah suatu yang mesti dan tidak sah akad perkawinan yang tidak dilakukan oleh wali. Wali itu ditempatkan sebagai rukun dalam perkawinan menurut kesepakatan ulama secara prinsip.

Rukun dan syarat adalah hal yang harus diperhatikan dalam perkawinan, karena rukun dan syarat akan menentukan sah dan tidaknya suatu perkawinan. Rukun nikah adalah sesuatu yang wajib ada dalam sebuah perkawinan. Karena bila rukun tidak terpenuhi maka perkawinan tersebutakan batal. Begitu juga dengan syarat yang mengikuti rukun, apabila tidak terpenuhi maka perkawinan itu akan fasid. Rukun nikah ada lima yaitu: calon mempelai pria, calon mempelai wanita, wali, dua orang saksi dan ijab qabul. ${ }^{4}$ Sedangkan dalam Kompilasi Hukum Islam menyebutkan rukun nikah ada lima,dalam Pasal14, yaitu calon suami, calon isteri, wali nikah, dua orang saksi, dan ijab dan qabul. ${ }^{5}$

Perkawinan dalam Tata Hukum Indonesia, khususnya bagi yang pemeluk agama Islam mewajibkan adanya wali dalam perkawinan. Kewajiban tersebut dapat dilihat dalam aturan yang dikeluarkan oleh pemerintah,antara lain dalam Kompilasi Hukum Islam Pasal19 sampai Pasal 23 dan Peraturan Menteri Agama Nomor 11 Tahun 2007 tentang Pencatatan Nikah Pasal 18. Keharusan adanya wali dalam perkawinan pada dasarnya merupakan kesepakatan mayoritas ulama, kecuali madzhab Hanafiyah yang tidak mensyaratkan wali bagi perempuan, apalagi jika perempuan tersebut telah dewasa dan mampu mempertanggungjawabkan setiap perkataan dan perbuatannya. ${ }^{6}$

Wali nikah menurut mayoritas ulama maupun dalam peraturan perundang-undangan di Indonesia merupakan sesuatu yang harus ada. ${ }^{7}$ Karena wali nikah merupakan keharusan, maka konsekuensi dari tidak adanya wali adalah nikah tersebut dihukumi tidak sah. Meskipun para ulama berbeda pendapat tentang kedudukan wali tersebut, apakah wali harus hadir dalam prosesi akad nikah ataukah wali hanya diperlukan izinnya. ${ }^{8}$

Perwalian dalam perkawinan adalah suatu kekuasaan atau wewenang syare I atas segolongan manusia, yang dilimpahkan kepada orang yang sempurna, karena kekurangan tertentu pada orang yang dikuasai itu, demi kemaslahatannya sendiri. Masalah perwalian terjadi perbedaan pendapat dari para imam mahzab. Imam Syafieci, Maliki, Hanbali berpendapat jika wanita tersebut baligh dan berakal sehat itu masih gadis, maka hak mengawinkan dirinya ada pada wali, akan tetapi jika ia janda maka hak itu ada pada keduanya. ${ }^{9}$

Pada kenyataannya, wali nikah seringkali menjadi permasalahan atau halangan dalam melangsungkan suatu perkawinan karena wali nikah yang paling berhak ternyata tidak bersedia atau menolak untuk menjadi wali bagi calon mempelai perempuan dengan berbagai alasan, baik alasan yang dibenarkan oleh syara' maupun yang bertentangan

\footnotetext{
${ }^{1}$ Miriam Budiardjo. 2009.Dasar-dasar Ilmu Politik.Gramedia Pustaka,Jakarta.hlm.52.

${ }^{2}$ Tim RedaksiCitra Umbara. 2013. Undang-Undang Nomor1 tahun 1974. Citra Umbara, Bandung, hlm.2.

${ }^{3}$ M.R. Martiman Prodjohamidjojo. 2011. Hukum Perkawinan Indonesia. Karya Gemilang, Jakarta, hlm. 1

${ }^{4}$ Abi Bakribin Muhammadal Hussaini. 2004. Kifayatal Ahyarfi Halli Ghayatal Ikhtishar. DaralFikr, Beirut-Libanon,
} hlm.40.

${ }^{5}$ Tim Redaksi Citra Umbara. 2013. Kompilasi Hukum Islam, Citra Umbara, Bandung, hlm.327.

${ }^{6}$ Ibid, hlm. 328, hlm.549.

${ }^{7}$ Yayasan Penyelenggara Penterjemah Al Qur'an DepagRI. 2008. AlQur'an dan Terjemahnya, AlWaah Semarang,

${ }^{8}$ Ibnu Hajar Al Asqalani. 2010. Bulughal Maramminadillatal Ahkam. Toha Putera, Semarang, hlm.204.

9 Muhammad Jawad Mughniyah. 2010. Fiqhala Madzahiba lKhamsah, terj.Afifi Muhammad, Idrus Al-Kaff, MasykurA.B., Fiqih Lima Mazhab, Lentera, Jakarta, hlm.345. 
dengan syara'.

Wali yang menolak atau tidak bersedia menikahkan disebut dengan istilah adhal (enggan). Menurut para ulama "definisi waliadhal adalah penolakan wali untuk menikahkan anak perempuan nya yang berakal dan sudah baligh dengan laki-laki yang sepadan dengan perempuan itu. Jika perempuan tersebut telah meminta (kepada walinya) untuk dinikahkan dan masing-masing calon mempelai itu saling mencintai, maka penolakan demikian menurut syara dilarang. ${ }^{10}$

Berdasarkan definisi tersebut dapat disimpulkan bahwa wali dinyatakan adhal apabila: adanya penolakan (keengganan) wali untuk menikahkan calon mempelai perempuan, telah ada permintaan atau permohonan darii calon mempelai perempuan agar dirinya dinikahkan dengan calon mempelai laki-laki, Kafa'ah antara calon mempelai lakilaki dan calon mempelai perempuan, adanya perasaan saling menyayangi atau mencintai di antara masing-masing calon mempelai dan alasan penolakan atau keengganan wali tersebut bertentangan dengan syara.

Ketentuan mengenai wali adhal dalam hukum perkawinan Indonesia diatur dalam beberapa peraturan perundang-undangan, yaitu:

a. Kompilasi Hukum Islam( KHI)

Ketentuan mengenai wali adhal dalam Kompilasi Hukum Islam diatur dalam Pasal 23. Pada dasarnya sama dengan kedua Peraturan Menteri Agama diatas.

b. Peraturan Menteri Agama Nomor 30 Tahun 2005 tentang Wali Hakim.

c. Dalam peraturan tersebut, dinyatakan bahwa adhal nya wali merupakan salah satu syarat atau keadaan dibolehkannya wali hakim sebagai wali dalam perkawinan calon mempelai perempuan dengan calon mempelai laki-laki.Untuk menyatakan adhol nya wali, maka diperlukan penetapan dari Pengadilan Agama yang mewilayahi tempat tinggal calon mempelai perempuan.

d. Peraturan Menteri Agama Nomor 11 Tahun 2007 tentang Pencatatan Nikah. ${ }^{11}$

Ketentuan mengenai wali adhal dalam peraturan ini sama dengan ketentuan dalam peraturan tersebut di atas. Penetapan bahwa seorang wali dinyatakan adhal harus di dasarkan pada pertimbangan yang sesuai dengan syari'at. Oleh karena itu, jika wali menghalangi karena alas an yang sah, seperti laki-lakinya tidak sepadan, atau maharnya kurang dari mahar mitsil, atau ada peminang lain yang lebih sesuai dengan derajatnya, maka dalam keadaan seperti ini perwalian tidak pindah ke tangan orang lain, karena wali tidak dianggap enggan atau adhal. ${ }^{12}$

Jika hal tersebut terjadi, maka Pegawai Pencatat Nikah pada Kantor Urusan Agama akan mengeluarkan surat penolakan perkawinan dengan alasan wali nikah tidak bersedia menikahkan calon mempelai perempuan dengan calon mempelai laki-laki atau walinya adhal. Calon mempelai perempuan yang keberatan dengan itu dapat mengajukan permohonan penetapan wali adhal kepada Pengadilan Agama yang mewilayahi KUA yang mengeluarkan surat penolakan tersebut.

Pengadilan Agama pada hakikatnya membahas terkait masalah penegakan hokum Islam diIndonesia.Pasal 2 Undang-undang Nomor 3 Tahun 2006 tentang PeradilanAgama menyebutkan bahwa Peradilan Agama adalah salah satu pelaku kekuasaan kehakiman bagi rakyat pencari keadilan yang beragama Islam mengenai perkara tertentu sebagaimana dimaksud dalam Undang-undang ini.Termasuk perkara tertentu dalam halini adalah permohonan penetapan wali adhal. ${ }^{13}$

Perkara wali adhal di Pengadilan Agama Metro dari tahun ke tahun tergolong sedikit dibandingkan dengan perkara perceraian, akan tetapi yang menarik minat penulis dalam penetapan wali adhal antara penetapan yang satu dengan penetapan yang lain terdapat perbedaan dalam dasar hukum yang dipakai oleh hakim dalam menetapkan perkara wali adhal. Salah satunya adalah pada Putusan Nomor 0055/ Pdt. P/ 2019/PA.Mt, dimana pada putusan tersebut mengabulkan permohonan pencabutan perkara Nomor 0055/Pdt.G/2019/PA.Mt tanggal 14 Agustus 2019 dari Pemohon, memerintahkan panitera untuk mencatat pencabutan perkara tersebut dalam register perkara dan memerintahkan Pemohon untuk membayar biaya perkara sejumlah Rp. 481.000,00 (empat ratus delapan puluh satu ribu rupiah).

${ }^{10}$ Wahbahal Zuhaili. 2011, al Fiqh allslamwa Adillatuhu, Juz 9, terj. Abdul Hayyieal Kattani, dkk, GemaInsani, Jakarta, hlm.470.

11 Abddul Ghofur Anshori. 2008. Hukum Islam, Dinamika dan Perkembangannya di Indonesia. Total Media, Jogjakarta, hlm 15-16

${ }^{12}$ Sayyid Sabiq. 2008. Fiqh Sunnah, Juz 3,terj. Abdurrahim dan Masrukhin. Cakrawala, Jakarta, hlm.386. hlm.43.

${ }^{13}$ Tim Redaksi Sinar Grafika. 2012. Undang-Undang Nomor 7 Tahun1989 tentang Peradilan Agama. Sinar Grafika, 


\section{METODE}

\section{Metode Pendekatan}

Penelitiaan ini mengunakan pendekatan yang bersifat yuridis normatif dan empiris.

1. Pendekatan yuridis normatif adalah dengan menggunakan pendekatan perundang-undangan yang terkait hukum perkwinan.

2. Pendekatan Empiris, pendekatan yang dilakukan melalui penelitian secara langsung terhadap objek penelitian dengan cara observasi dan wawancara.

3. Sumber Data terdiri dari bahan:

a. Bahan Hukum Primer.

Bahan hukum primer yaitu bahan hukum yang mengikat, yaitu:

1) UUD NRI 1945 hasil amandemen keempat

2) Kitab Undang-Undang Hukum Perdata.

3) Undang-undang No. 1 Tahun 194 tentang Perkawinan.

4) Undang-undang Nomor 3 Tahun 2006 tentang Peradilan Agama .

5) Peraturan Menteri Agama Nomr 30 Tahun 2005 tentang Wali Adhal.

6) Peraturan Menteri Agama Nomor 11 Tahun 2007 tentang Pencatatan Nikah

b. Bahan Hukum Sekunder

Bahan hukum sekunder yaitu bahan hukum yang menjelaskan bahan hukum primer, antara lain berupa buku, hasil-hasil penelitin, tulisan dan pendapat pakar-pakar hukum.

c. Bahan Hukum Tertier.

Bahan hukum tertier yaitu bahan hukum yang sifatnya penunjang untuk dapat member petunjuk dan penjelsan terhadap bahan hukum primer dan sekunder, seperti jurnal hukum, jurnal ilmiyah, surat kabar, internet dan makalah yang berkaitan dengan objek penelitian.

\section{Prosedur Pengumpulan Data dan pengolahan Data.}

\section{Data Sekunder.}

Pengolahan data melalui studi kepustakaan (Libray Research) dengan cara mempelajari literature untuk memperoleh data sekunder yang berhubungan dengan maslah yang diteliti berupa asas-asas hukum, peraturanperaturan hukum dan bahan hukum lain yang berkaitan dengan masalah yang diteliti.

2. Data Primer

a. Pengamatan (observasi) dilaksanakan dengan jalan mengamati objek penelitian.

b. Wawancara (interview) dilakukan dengan untuk mengumpulkan data primer yaitu dengan cara wawancara langsung secara terarah terhadap nara sumber yang terkait dengan permasalahan penelitian tersebut. Penulis wawancara dengan:

1) Hakim Pengadilan Metro : 1 Orang

2) Petugas Pencatat Nikah Metro " 1 Orang.

\section{Analisis Data}

Analisis data yang digunakan analisis data Yuridis Kualitatif, yaitu dengan memberikan pengertian terhadap data yang dimaksud menurut kegiatan yang diperleh di lapangan dan disusun serta diuraikan dalam bentuk kalimat.

\section{HASIL DAN PEMBAHASAN \\ Hukum Formil dalam Penetapan Pengadilan Agama Metro Nomor 0055/Pdt P/2019/PA.Mt tentang Dikabulkannya Permohonan Wali Adhal}

Semua manusia memiliki kodrat berpasang-pasangan, setiap manusia yang sudah dewasa dan sehat jasmani rohani pasti membutuhkan teman hidup yang berbeda jenis kelaminnya. Teman hidup tersebut tidak hanya untuk seekedar memenuhi kebutuhan biologis semata tetap ijuga untuk bias diajak bekerjasama dalam mewujudkan ketentraman dan kesejahteraan hidup. Dalam hal ini Islam telah mengatur semua itu melalui pernikahan.

Di dalam pernikahan terdapat syarat dan rukun, salah satunya yaitu wali nikah. Wali adalah orang yang melakukan akad atau mengakadkan nikah sehingga nikah menjadi sah. Pernikahan sangat perlu adanya perwalian yaitu wali dari mempelai perempuan dan sebagai wali itu tidak boleh enggan (Adhal) untuk menikah kan anak perempuannya jika anak perempuan sudah mempunyai calon yang baik dan sekufu. Suatu pernikahan bila dilangsungkan tanpa wali, atau yang menjadi wali bukan orang yang berhak, maka pernikahan tersebut batal atau tidak sah. Ahli Zhahir berpendapat bahwa wali disyaratkan untuk perkawinan perempuan bikir (perawan) dan tiada disyaratkan untuk perkawinan perempuan isaib (janda).

Hukum formil (hukum acara) adalah rangkaian peraturan-peraturan yang memuat cara bagaimana orang harus bertindak di muka Pengadilan dan bagaimana cara Pengadilan harus bertindak satu sama lain untuk melaksanakan 
perjalanannya peraturan-peraturan hukum perdata. Suatu penetapan yang merupakan produk hukum dari persidangan terhadap suatu perkara harus sesuai dengan hukum formil dan materil yang berlaku. Jika salah satu dari unsur tersebut tidak terpenuhi maka bisa dikatakan suatu putusan/penetapan tersebut cacat hukum. Jalan keluar yang diberikan oleh peraturan perundang-undangan terhadap orang yang belum memahami hukum formil dan materil adalah sebagaimana diatur dalam Pasal 119 HIR dan pasal 143 R.Bg dimana dikemukakan bahwa ketua Pengadilan berwenang memberikan nasihat dan bantuan kepada Penggugat atau kuasanya dengan tujuan agar tidak mengalami kesulitan dalam membuat gugatan bagi orang-orang yang kurang pengetahuannya tentang hukum formil dan materil.

Berdasarkan hasil wawancara dengan H. Mai'muri selaku Hakim Pengadilan Agama Metro menyatakan bahwa untuk mengetahui kebenaran dan sesuai atau tidaknya dengan hukum, maka pennulis akan membandingkan praktik penyelesaian perkara wali adhal yang dilaksanakan oleh Pengadilan Agama Metro dengan prosedur penyelesaian perkara wali adhal pada Pengadilan Agama yaitu sebagai berikut:

1. Untuk menetapkan adhalnya wali harus ditetapkan dengan keputusan Pengadilan Agama. Penetapan hari siding pada perkara wali adhal yang ditetapkan oleh Pengadilan Agama Metro.

2. Calon mempelai wanita yang bersangkutan mengajukan permohonan penetapan adhalnya wali dengan surat permohonan.

3. Adapun surat permohonannya adalah sebagai berikut:

Identitas calon mempelai wanita sebagai Pemohon

$\begin{array}{ll}\text { Nama } & : \text { xxxxx } \\ \text { Umur } & : 21 \text { tahun } \\ \text { Agama } & : \text { Islam } \\ \text { Pekerjaan } & : \text { xxxxx } \\ \text { Tempat tinggal } & : \text { Kota Metro }\end{array}$

Berdasarkan hasil wawancara dengan H. Mai'muri selaku Hakim Pengadilan Agama Metro menyatakan bahwa uraian tentang pokok perkara adalah.

1. Bahwa pemohon dengan calon suami pemohon telah saling mencintaidan hubungan mereka sudah sedemikian eratnya sehingga sulit untuk dipisahkan dan sepakat untuk melangsungkan pernikahan.

2. Bahwa antara Pemohon dengan calon suami pemohon tidak ada hubungan nasab ataupun hubungan sesusuan yang menjadi halangan bagi Pemohon dan calon suami Pemohon untuk melangsungkan pernikahan.

3. Bahwa pemohon, calon suami dan perangkat Pengadilan sudah berusaha membujuk ayah Pemohon agar berkenan menikahkan Pemohon tetapi ayah Pemohon tetap tidak mau dengan alas an yang tidak masuk akal.

4. Petitum, yaitu mohon ditetapkan adholnya wali dan ditunjuk wali hakim untuk menikahkannya.

5. Permohonan diajukan ke Pengadilan Agama di tempat tinggal calon mempelai wanita (Pemohon)

6. Perkara penetapan adhalnya wali berbentuk voluntair.

Berdasarkan hasil wawancara dengan Ahmad Gunawanselaku Kepala Kantor Urusan Agama (KUA) Kecamatan Metro Pusat Kota Metro menyatakan bahwa permohonan wali adhal di Pengadilan Agama diproses sebagai perkara voluntair (kepentingan sepihak) yaitu permasalahan perdata yang diajukan dalam bentuk permohonan yang ditandatangani oleh Pemohon/kuasanya yang ditujukan kepada ketua Pengadilan Agama,dan dalam penetapan ini ayah Pemohon tidak mempunyai upaya hukum banding maupun kasasi Karena perkara ini hanya melibatkan calon mempelai wanita sebagai pemohon tanpa ada pihak lain yang dijadikan sebagai termohon dan jika perkara tersebut diputus secara contentious, maka perkara tersebut akan memperlambat perkawinan dari kedua belah pihak calon mempelai, dan akan menimbulkan kemadhorotan jika tidak segera ditetapkan, diantara kemadharatan itu adalah bisa berbuat zina hingga hamil diluar nikah, sedangkan hal seperti itu tidak sesuai dengan hukum Islam.

Pengadilan Agama menetapkan sidang nya dengan memanggil Pemohon dan memanggil pula wali Pemohon tersebut untuk didengar keterangannya di dalam persidangan, kepada para pihak diberitahukan pula untuk mempersiapkan beserta para saksi dan bukti yang dikehendaki untuk diperiksa. Pengadilan Agama memeriksa dan menetapkan adhalnya wali dengan cara singkat. Pihak wali sebagai saksi utama telah dipanggil secara resmi dan patut, namun tetap tidak hadir sehingga tidak dapat didengar keterangannya, maka hal ini dapat memperkuat adhalnya wali. Akan tetapi apabila pihak wali telah hadir dan memberikan keterangan nya, maka hakim harus mempertimbangkan dengan mengutamakan kepentingan Pemohon terlebih dahulu.

Untuk memperkuat adanya adhaln ya wali, maka perlu didengar keterangan saksi-saksi maupun bukti tertulis yang tercantum dalam penetapan yaitu P.1, P.2, P.3, P.4, dan P.6.agar tidak sepihak untuk menggaliin formasi. Apabila wali yang enggan menikahkan tersebut mempunyai alasan-alasan yang kuat menurut hokum perkawinan dan sekiranya perkawinan tetap dilangsungkan justru akan merugikan Pemohon atau terjadinya pelanggaran terhadap larangan perkawinan, maka permohonan Pemohon akan ditolak. Adapun alasan-alasan tersebut adalah: 
a. Adahubungan darah dalam garis lurus vertical maupun horizontal.

b. Ada hubungan semenda

c. Ada hubungan sepersusuan.

Jika ada alasan seperti di atas maka permohonan oleh Pemohon akan ditolak majelis.

Berdasarkan proses penyelesaian tersebut, maka hakim berpendapat bahwa wali telahbenar-benar adhal dan Pemohon tetap pada permohonannya maka hakim akan mengabulkan permohonan Pemohon dengan menetapkan adholnya wali dan menunjuk kepada KUA Kecamatan, selaku Pegawai Pencatat Nikah (PPN), ditempat tinggal Pemohon untuk bertindak sebagai wali hakim.

Sebelum akad nikah dilangsungkan, wali hakim meminta kembali kepada Wali Nasabnya untuk menikahkan calon mempelai wanita, sekali pun sudah ada penetapan PengadilanAgama tentang adhalnya wali. Apabila wali nasabnya tetap adhal, maka akad nikah dilangsungkan dengan wali hakim. Pemeriksaan dan penetapan adhalnya wali bagi calon memepelai wanita warga Negara Indonesia yang bertempat tinggal diluar negeri dilakukan oleh wali hakim yang akan menikah kan calon mempelai wanita. Wali hakim pada perwakilan Republik Indonesia di luar negeri dapat ditunjuk pegawai yang memenuhi syarat menjadi wali hakim, oleh Direktur Jendral Bimbingan Masyarakat Islam dan Urusan Haji atas nama Menteri Agama.

Berdasarkan cara penyelesaian perkara wal iadhal diPengadilan Agama MetroNomor0055/Pdt.P/2019/PA.Mt tentang permohonan wali adhal dengan prosedurdi Pengadilan Agama bahwa sudah sesuai dengan hukum formil yang berlaku, dan tidak cacat hukum dalam pelaksanaannya dipersidangan PengadilanAgama Metro. Untuk menetapkan wali hakim sebagai wali nikah dari perempuan yang wali nasabnya adhal maka Pengadilan Agama Metro mendasarkan pada Peraturan Menteri Agama No.2 Tahun 1987 tentang Wali Hakim dan KHI (Kompilasi Hukum Islam) Pasal 23 ayat (1) dan (2) yaitu:

(1) Wali hakim baru dapat bertindak sebagai wali nikah apabila wali nasab tidak ada atau tidak mungkin menghadirkannya atau diketahui tempat tinggalnya atau ghaib atau adhal atau enggan.

(2) Dalam hal wali adha latau enggan maka wali hakim baru bertindak sebagai wali nikah setelah ada putusan Pengadilan Agama tentang wali tersebut.

Dengan demikian penetapan Pengadilan Agama Metro yang telah mengabulkan permohonan wali adhal dan mendapatkan wali hakim dinilai telah sesuai dengan hokum yang berlaku, bahkan jika melihat dari kemudhorotan dan maslahatnya maka ini harus dilakukan demi menghindari hal yang tidak diinginkan oleh syara'.

Berdasarkan uraian di atas, maka dapat dianalisis bahwahukum formil dalam penetapan Pengadilan Agama Metro No.0055/Pdt.P/2019/PA.Mt tentang dikabulkannya permohonan wali adhal, yaitu: Pengadilan Agama Metro telah mengabulkan permohonan wali adhal dan menetapkan wali hakim sebagai wali nikah dari anak perempuan (Pemohon) yang walinya adhal, maka Pengadilan Agama Metro mendasarkan pada Peraturan Menteri Agama No.2 Tahun1987 tentang wali hakim dan Kompilasi Hukum Islam Pasal 23 ayat 2 yaitu dalam hal wali adhal atau enggan maka wali hakim baru bertindak sebagai wali nikah setelah ada putusan dari Pengadilan Agama tentang walitersebut, danperkara penetapan wali adhal ini merupakan perkara voluntair, karena hanya ada Pemohon saja tanpa ada Termohon. Bahkan perkara ini tidak mempunyai upaya hukum banding maupun kasasi karena hanya bersifat sepihak saja.

\section{Dasar Pertimbangan Hakim (Hukum Materil) dalam Memutuskan Penetapan Pengadilan Agama Metro Nomor 0055/Pdt P/2019/PA.Mt tentang Dikabulkannya Permohonan Wali Adhal}

Hukum materil adalah segala hukum pokok yang mengatur kepentingan- kepentingan perseorangan. Dalam hal ini merupakan hukum yang memuat peraturan-peraturan yang mengatur kepentingan yang berwujud perintah dan larangan dimana dalam suatu penetapan terdapat pertimbangan hukum. Dalam perkara ini Pemohon akan melangsungkan pernikahan dengan laki-laki pilihannya yang dinilai cukup memenuhi syarat sebagai calon suami yang baik bagi Pemohon. Dari maksud tersebut calon suami Pemohon dan orang tuanya sudah datang kepada wali Pemohon untuk melamar Pemohon, bahkan sudah datang untuk melamar sampai 2 (dua) kali, dan ayah Pemohon tetap menolak, karena alasan penolakan tersebut, Pemohon mengajukan permohonan penetapan wali adhal ke Pengadilan Agama Metro dan hasilnya permohonan tersebut dikabulkan.

Berdasarkan hasil wawancara dengan H. Mai'muri selaku Hakim Pengadilan Agama Metro menyatakan bahwa padaperkara ini ditemukan beberapa pertimbangan hakim dalam beberapa pertimbangan yang telah tercantum dalam berkas penetapan permohonan wali adhal iniyaitu:

a. Antara Pemohon dan calon suami Pemohon tidak ada larangan untuk melaksanakan pernikahan karena keduanya tidak ada hubungan mahram atau sesusuan bahkan orang lain. 
b. Berdasarkan keterangan saksi dan bukti, telah terbukti bahwa wali nikah Pemohon menolak untuk menikahkan Pemohon dengan calon suaminya dengan alasan yang tidak jelas.

c. Penolakan wali nikah kepada Pemohon untuk menikahkan Pemohon dengan calon suami tidak berdasarkan hukum.

d. Penolakan wali nikah kepada Pemohon untuk menikahkan Pemohon dengan calon suami tidak sesuai dengan syar'i.

e. Tidak hadirnya wali nikah Pemohon di persidangan dipandang tidak hendak membantah permohonan Pemohon.

f. Pertimbangan hakim melihat dari hubungan Pemohon dan calon suaminya agar tidak terjadi penyimpahan dan pelanggaran hukum.

Berdasarkan hasil wawancara dengan Ahmad Gunawan selaku Kepala Kantor Urusan Agama (KUA) Kecamatan Metro Pusat Kota Metro menyatakan bahwa Pertimbangan hakim tersebut akan penulis analisis untuk dapat diketahui dasar hukum yang digunakan.

1. Antara Pemohon dan calon suaminya tidak ada larangan untuk melaksanakan pernikahan.

Pada dasarnya laki-laki muslim dapat saja menikah dengan wanita yang disukainya. Namun prinsip itu tidak mutlak karena ada batasannya dalam bentuk larangan perkawinan menurut hukum Islam. Dalam memandang perkara ini bahwa salah satu pertimbangan hakim adalah melihat calon mempelai perempuan dalam pinangan orang lain atau tidak, kemudian dalam hubungan mahram atau tidak, masih sepersusuan atau tidak dengan calon suaminya. Dalam perkara ini Pemohon dancalon suaminya telah memenuhi syarat-syarat dan tidak ada larangan untuk melaksanakan pernikahan karena Pemohon tidak sedang dalam pinangan orang lain dan juga tidak ada hubungan pertalian darah, tidak ada hubungan mahram ataupun persusuan dengan calon suami Pemohon.

2. Berdasarkan keterangan saksi dan bukti tentang terbuktinya wali nikah Pemohon menolak untuk menjadi wali dalam pernikahan Pemohon dengan calon suaminya. Hal ini menunjukkan bahwa dasar yang digunakan majlis hakim untuk menetapkan adhalnya wali dalam pernikahan adalah adanya bukti-bukti dan fakta-fakta hukum yang berkaitan dengan perkara tersebut. Dalam hukum pembuktian Pasal163HIR/283R.Bg dijelaskan bahwa barang siapa mengatakan mempunyai suatu hak atau mengemukakan suatu perbuatan untuk meneguhkan haknya itu, atau untuk membantah hak orang lain, haruslah membuktikan adanya hak itu atau adanya perbuatan itu.

Sementara itu alat bukti dalam hal ini berupa bukti surat dan saksi. Bukti surat yang pokok dalam perkarawal iadhal adalah surat keterangan yang dikeluarkan oleh Kantor Urusan Agama (KUA) setempat (P.1) yakni bahwa ternyata walinya tidak bersedia menjadi wali. Sedangkan saksi adalah orang-orang yang mengetahui adanya permasalahan tersebut dan saksi akan dimintai keterangan mengenai adhalnya wali dan juga keadaan kedua Pemohon dan calon suami Pemohon.

3. Penolakan walinikah kepada Pemohon untuk menikahkan Pemohon dengan calon suami tidak berdasarkan hukum.

Alasan penolakan wali nikah untuk menikahkan Pemohon dengan calon suaminya dinyatakan hakim sebagai perbuatan yang tidak berdasarkan hukum. Para ulama berpendapat bahwa wali tidak berhak merintangi perempuan yang di bawah perwaliannya, bila ia mencegah kelangsungan pernikahan tersebut tanpa alasan yang jelas berarti dia berbuat zhalim.

Dalam hal ini majelis hakim harus menetapkan wali Pemohon sebagai wali adhal karena sudah jelas bahwa wali Pemohon menolak untuk menikahkan. Jika wali menghalangi karena alasan-alasan yang dibenarkan syara', dan apabila wali yang enggan menikahkan mempunyai alasan-alasan yang kuat menurut hukum perkawinan itu tetap dilangsungkan maka akan merugikan Pemohon, maka permohonan Pemohon akan ditolak. Akan tetapi dalam perkara penetapan adhalnya wali yang engggan menjadi wali anaknya karena calon suami yang bernama Andi Saputra bin Sopyan Yusup majelis hakim melihat bahwa alasan penolakan wali tersebut tidak sesuai denngan syara'.

Dalam hal ini dijelaskan oleh Peraturan menteri agama Republik Indonesia Nomor 2 tahun1987 bab II pasal 2 tentang penetapan adhalnya wali yaitu:

(1) Bagi calon mempelai wanita yang akan menikah diwilayah Indonesia atau diluar negeri/wilayah ekstrateritorial Indonesia ternyata tidak mempunyai wali nasab yang berhak atau wali nasabnya tidak memenuhi syarat atau mafqud atau berhalangan atau adhal, maka nikahnya dapat dilangsungkan dengan Wali Hakim.

(2) Untuk menyatakan adhalnya wali sebagaimana tersebut ayat (1) Pasal ini ditetapkan dengan keputusan Pengadilan Agama yang mewilayahi tempat tinggal calon mempelai wanita.

(3) Pengadilan Agama memeriksa dan menetapkan adhalnya wali dengan cara singkat atas permohonan calon mempelai wanita dengan menghadirkan wali calon mempelai wanita.

4. Ketidakhadiran wali nikah Pemohon dalam persidangan dipandang tidak hendak membantah Permohonan dari Pemohon. Ketidakhadiran wali nikah Pemohon dalam persidangan itu dipandang tidak hendak membantah permohonan dari Pemohon dalam persidangan. Sedangkan didalam urusan perkara perdata, kedudukan hakim adalah sebagai penengah diantara pihak yang berperkara, perlu memeriksa, memutus, dan mendengarkan dengan 
teliti terhadap pihak-pihak yang berselisih itu. Itulah sebabnya pihak-pihak pada prinsipnya harus semua hadir di dalam persidangan.

Berdasarkan prinsip ini maka diperbolehkan memanggil ayah Pemohon yang kedua kalinya (dalam sidang pertama), sebelum ia digugurkan. Karena kemungkinan ada para pihak yang tidak hadir dengan berbagai sebab dan keadaannya atau bahkan mungkin ada yang membangkang, maka demi kepastian hukum, cara-cara pemanggilan sidang diatur kongkrit sehingga jika terjadi penyimpangan dari prinsip, perkara tetap dapat diselesaikan.

Wali dari Pemohon bukanlah sebagai pihak termohon, akan tetapi saksi yang perlu dihadirkan didepan sidang untuk didengar keterangannya dalam kepentingan pemeriksaan, karena wali tersebut mempunyai hubungan hukum langsung dengan Pemohon. Jadi apabila permohonan cukup beralasan atau terbukti maka permohonannya akan dikabulkan dan jika tidak terbukti permohonan akan ditolak.

Dalam hal ini wali Pemohon telah dipanggil 2 kali dipersidangan namun tidak hadir walaupun telah dipanggil secara patut, sedangkan tidak datangnya wali didalam persidangan tidak disebabkan oleh suatu halangan yang sah. Jadi tidak memberitahukan bahwa lagi sakit atau sedang pergi, sehingga berarti sudah dianggap benar karena tidak membantah akibat ketidakhadirannya. Tidak membantah artinya mengakui, jika sudah mengakui maka menjadi fakta bahwa wali tersebut adhal untuk menikahkan puterinya.Oleh karena itu, walau pun wali dari Pemohon membangkang untuk hadir memberikan keterangan mengenai alasannya menolak untuk menjadi wali dari Pemohon, majelis hakim tetap bisa mendapatkan informasi dari beberapa saksi yang telah dihadirkan dalam persidangan. Maka demi kepastian hukum, perkara permohonan wali adhal karena calon suami bekerja sebagai buruh pabrik dan hanya lulusan SD ini maka tetap dapat diselesaikan.

5. Pertimbangan hakim melihat dari hubungan Pemohon dan calon suaminya agar tidak terjadi penyimpangan dan pelanggaran hukum.

Bahwa hakim juga mempertimbangkan kemaslahatan dan kemudhorotan yang akan timbul jika tidak segera menunjuk wali hakim untuk menikahkan. Sehingga kekhawatiran atau bahaya yang akan timbul itu harus segera dicegah dengan jalan pernikahan. Karena kemudhorotan yang akan terjadi lebih besar jika para hakim tidak mengabulkan permohonan wali adhalnya, diantara kemudhorotan tersebut adalah, hamil diluar nikah, berbuat zina (kumpul kebo), kawin lari, bahkan nikah sirri. Oleh karena itu sikap adhalnya wali tidak dibenarkan oleh syari'at Islam, karena sudah menjadi kewajiban orang tua (wali) untuk menikahkan anak perempuannya.

Berdasarkan uraian di atas, maka dapat dianalisis bahwa dasar pertimbangan hakim (hukum materil) dalam memutuskan Penetapan Pengadilan Agama Metro Nomor 0055/Pdt.P/2019/PA.Mt tentang dikabulkannya permohonan wali adhal adalah hakim melihat alasan penolakan wali tersebut tidak termasuk dalam alas an yang dibenarkan oleh hokum syara', karena alasan seorang wali yang tidak setuju dengan calon suami anaknya yang bernama Andi Saputra bin Sopyan Yusup tidak menjadi pertimbangan utama sehingga wali dinyatakan adhal oleh pengadilan, bahkan saat wali dipanggil 2 kali oleh Pengadilan Agama untuk dimintai keterangan, wali tidak hadir dan tidak memberikan alasan yang jelas,bahkan secara hukum syara' antara Pemohon dan calon suaminya tidak ada larangan untuk melaksanakan pernikahan karena tidak ada hubungan mahram maupun persesusuan. Sehingga solusinya untuk menghindari kemudhorotan adalah perkaraini segera ditetapkan untuk menghin dari hal-hal yang tidak baik misalnya hamil diluar nikah, berbuat zina (Kumpul kebo), kawin lari, bahkan nikah sirri dan hal ini dilarang oleh hukum Islam.

\section{SIMPULAN}

Berdasarkan hasil penelitian dan pembahasan, maka dapat diambil simpulan sebagai berikut:

1. Hukum Formil dalam penetapan Pengadilan Agama Metro No.0055/Pdt.P/2019/PA.Mt tentang dikabulkannya permohonan wali adhal, yaitu: Pengadilan Agama Metro telah mengabulkan permohonan wali adhal dan menetapkan wali hakim sebagai wali nikah dari anak perempuan (Pemohon) yang walinya adhal,maka Pengadilan Agama Metro mendasarkan pada Peraturan Menteri Agama No.2 Tahun 1987 tentang wali hakim dan Kompilasi Hukum Islam Pasal 23ayat (2) yaitu dalam hal wali adha latau enggan maka wali hakim baru bertindak sebagai wali nikah setelah ada putusan dari Pengadilan Agama tentang wali tersebut, dan perkara penetapan wali adhal ini merupakan perkara voluntair, karena hanya ada Pemohon saja tanpa ada Termohon. Bahkan perkara ini tidak mempunyai upaya hukum banding maupun kasasi karena hanya bersifat sepihak saja.

2. Dasar pertimbangan hakim (hukum materil) dalam memutuskan Penetapan Pengadilan Agama Metro Nomor 0055/Pdt.P/2019/PA.Mt tentang dikabulkannya permohonan wali adhal adalah hakim melihat alasan penolakan wali tersebut tidak termasuk dalam alas an yang dibenarkan oleh hukum syara', karena alasan seorang wali yang tidak setuju dengan calon suami anaknya yang bernama Andi Saputra bin Sopyan Yusup tidak menjadi pertimbangan utama sehingga wali dinyatakan adhal oleh pengadilan, bahkan saat wali dipanggil 2 kali oleh Pengadilan Agama untuk dimintai keterangan, wali tidak hadir dan tidak memberikan alasan yang jelas, bahkan secara hukum syara' antara Pemohon dan calon suaminya tidak ada larangan untuk melaksanakan pernikahan 
Baharudin, Implementasi Pertimbangan Hakim dalam Mengabulkan Permohonan Penetapan Wali Adhal Untuk Melaksanakan Perkawinan Menurut Hukum Islam (Studi Putusan Nomor 0055/ Pdt. P/2019/PA.Mt)

karena tidak ada hubungan mahram maupun persesusuan. Sehingga solusinya untuk menghin dari kemudhorotan adalah perkara ini segera ditetapkan untuk menghindari hal-hal yang tidak baik misalnya hamil diluar nikah, berbuat zina (Kumpul kebo), kawin lari, bahkan nikah sirri dan hal ini dilarang oleh hukum Islam.

\section{DAFTAR PUSTAKA}

Abddul Ghofur Anshori. Hukum Islam, Dinamika dan Perkembangannya di Indonesia. Total Media, Jogjakarta, 2008. Abi Bakribin Muhammadal Hussaini. .Kifayatal Ahyarfi Halli Ghayatallkhtishar.DaralFikr, Beirut-Libanon, 2004.

Ibnu Hajar AlAsqalani. 2010. Bulughal Maramminadillatal Ahkam.Toha Putera, Semarang.

Martiman Prodjohamidjojo. Hukum Perkawinan Indonesia. Karya Gemilang, Jakarta. 2011

Miriam Budiardjo, Dasar-dasar Ilmu Politik. Gramedia Pustaka, Jakarta. 2009

Muhammad Jawad Mughniyah. Qhala Madzahibal Khamsah, terj.Afifi Muhammad, Idrus Al-Kaff, Masykur A.B., Fiqih Lima Mazhab, Lentera, Jakarta. 2010

Sayyid Sabiq. Sunnah, Juz 3,terj. Abdurrahim dan Masrukhin. Cakrawala, Jakarta. 2008

Tim Redaksi Citra Umbara. Undang-Undang Nomor1 tahun 1974. Citra Umbara, Bandung. 2003

Tim Redaksi Citra Umbara. 2013. Kompilasi Hukum Islam, CitraUmbara, Bandung.

Tim Redaksi Sinar Grafika. 2012. Undang-Undang Nomor 7 Tahun 1989 tentang Peradilan Agama. Sinar Grafika.

Wahbahal Zuhaili. al Fiqh alIslamwa Adillatuhu, Juz 9,terj. Abdul Hayyieal Kattani, dkk., Gema Insani, Jakarta. 2011,

Yayasan Penyelenggara Penterjemah Al Qur'an Depag RI. AlQur'an dan Terjemahnya, AlWaah Semarang.2008 